\title{
Kidneys of Mice With Hereditary Tyrosinemia Type I Are Extremely Sensitive to Cytotoxicity
}

\author{
SASKIA M.M. JACOBS, DENIS H.A. VAN BEURDEN, LEO W.J. KLOMP, RUUD BERGER, AND INGE E.T. VAN DEN BERG
}

Department of Metabolic and Endocrine Diseases, University Medical Center Utrecht, Utrecht, The Netherlands

\begin{abstract}
Children with hereditary tyrosinemia type 1 (HT1) suffer from liver failure, renal tubular dysfunction, and rickets. The disease is caused by deficiency of fumarylacetoacetate hydrolase (FAH), the last enzyme of tyrosine catabolism, and leads to accumulation of the toxic substrate fumarylacetoacetate (FAA) in hepatocytes and renal proximal tubular cells. Patients are treated with 2-(2-nitro-4-trifluoro-methylbenzoyl)-1,3 cyclohexanedione (NTBC), which prevents accumulation of FAA by blocking an enzyme upstream of FAH. Liver transplantation is performed when patients do not respond to NTBC or develop hepatocellular carcinoma. This reduces the tyrosine load for the kidney but does not abolish renal exposure to locally produced FAA. To investigate the pathogenesis of liver and kidney damage induced by tyrosine metabolites, we challenged FAH-deficient mice with various doses of homogentisic acid (HGA), a precursor of FAA. Injecting NTBCtreated $\mathrm{Fah}^{-1-}$ mice with low doses of HGA caused renal damage and death of renal tubular cells, as was shown by histologic analyses and deoxynucleotidyl transferase-mediated dUDP nick-end labeling (TUNEL) assay but did not lead to liver damage. In addition, kidney function, but not liver function, was affected after exposure to low doses of HGA. Administration of high doses of HGA led to massive cell death in both the liver and kidneys. Resistance to HGA-induced cell death was seen after withdrawing NTBC from $\mathrm{Fah}^{-1-}$ mice. The finding that the kidneys of $\mathrm{Fah}^{-1-}$ mice are especially sensitive to damage induced by low doses of HGA underscores the need to perform careful monitoring of the kidney function of tyrosinemia patients undergoing any form of treatment. (Pediatr Res 59: 365370, 2006)
\end{abstract}

$\mathrm{H}^{1}$ T1 is a metabolic disorder of autosomal recessive inheritance that is caused by deficiency of FAH (EC 3.7.1.2.), the enzyme catalyzing the final step of tyrosine catabolism (Fig. 1). This enzyme defect leads to accumulation of the toxic substrate of FAH, FAA, in the liver and kidneys (1). Patients diagnosed with the acute form of HT1 (2) with symptoms appearing during the first months of life suffer from severe progressive liver disease that is life threatening. The late presenting form, which does not lead to clinical symptoms before the age of $6 \mathrm{mo}$, has a less aggressive progression and presents with renal tubular defects, hypophosphatemic rickets, and mild liver disease. Hepatocellular carcinoma (HCC) is a frequent complication of this form of HT1 $(3,4)$.

Received June 14, 2005; accepted October 10, 2005.

Correspondence: Inge E. T. van den Berg, M.D., Ph.D., University Medical Center Utrecht, Department of Metabolic and Endocrine Diseases, Room KC02.069.1, Lundlaan 6, 3584 EA Utrecht, The Netherlands; e-mail: I.vandenBerg@umcutrecht.nl

This project was supported by the Wilhelmina Children's Hospital Foundation.

DOI: 10.1203/01.pdr.0000198810.57642.b4
Until the early 1990s, the main therapy for HT1 was orthotopic liver transplantation (OLT) (5). OLT has a beneficial effect on the tubular dysfunction of some HT1 patients $(1,6)$, but patients who continued to have renal problems after successful OLT have also been reported (7-10). Since 1992, HT1 patients have been treated with NTBC in combination with a diet low in phenylalanine and tyrosine (11). NTBC reduces the accumulation of FAA by blocking the activity of 4-hydroxyphenylpyruvate dioxygenase (HPD), an enzyme acting upstream of FAH (Fig. 1), and has been shown to improve both liver and kidney function in approximately $90 \%$ of HT1 patients (12-14). The $10 \%$ of patients not responding to NTBC remain dependent on OLT for survival (15).

Now that both OLT and NTBC treatment have markedly increased the life expectancy of patients with HT1, studies are needed to answer the questions regarding the long-term problems that may be encountered during and after treatment of these patients. First, several HT1 patients have already been reported, who, despite NTBC treatment, developed HCC $(15,16)$. It is not clear yet which mechanisms lie at the basis of the development of liver cancer in these patients. Second, little is known about the sensitivity of the kidneys to damage induced by HT1, and the currently used doses of NTBC may not suffice to completely prevent deterioration of kidney function in NTBC-treated HT1 patients. Third, it is not known whether deterioration of kidney function induced by HT1 is a potential hazard for patients treated with OLT. To begin to address these questions, we extended our investigations of the development of liver and kidney damage in Fah knockout $\left(\mathrm{Fah}^{-\prime-}\right)$ mice, which provide a good model to investigate the pathogenesis of HT1. Without treatment, $\mathrm{Fah}^{-1-}$ mice die of acute liver failure, which can be prevented by NTBC treatment started prenatally (17). Exposure of NTBC-treated $\mathrm{Fah}^{-1-}$ mice to high doses of HGA, a tyrosine metabolite and precursor of FAA, induces massive cell death in their liver and kidneys. $\mathrm{Fah}^{-1-}$ mice, in which NTBC was withdrawn for $15 \mathrm{~d}$ and that developed the HT1 phenotype, acquire resistance to this form of cell death $(18,19)$. We then exposed the $\mathrm{Fah}^{-/-}$ mice, either treated with NTBC or untreated, to various doses of HGA. Subsequently, we investigated liver and kidney

Abbreviations: FAA, fumarylacetoacetate; FAH, fumarylacetoacetate hydrolase (EC 3.7.1.2.); HCC, hepatocellular carcinoma; HGA, homogentisic acid; HT1, hereditary tyrosinemia type 1; NTBC, 2-(2-nitro-4-trifluoromethylbenzoyl)-1,3 cyclohexanedione; OLT, orthotopic liver transplantation 


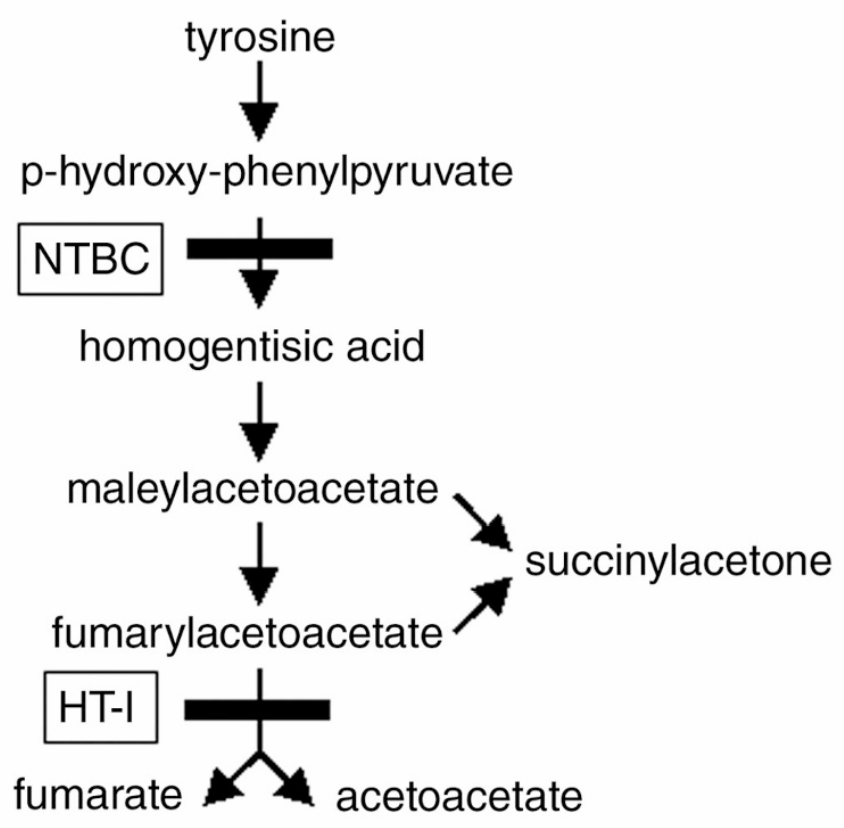

Figure 1. Tyrosine degradation pathway and HT1. The metabolites of the tyrosine degradation pathway are tyrosine, $p$-hydroxyphenylpyruvate, HGA, maleylacetoacetate, and FAA. The enzymes involved are, from top to bottom, tyrosine aminotransferase, $p$-HPD, HGA dioxygenase, maleylacetoacetate isomerase, and FAH. In HT1, the enzyme FAH is deficient. Excess FAA is partially converted to succinylacetone, which is pathognomonic for FAH deficiency. The drug NTBC blocks the enzyme HPD. HGA enters the tyrosine breakdown pathway downstream from the block imposed by NTBC.

function by performing various tests in plasma and urine and studied the histopathologic features of liver and kidneys.

\section{METHODS}

Animals and treatment. $\mathrm{Fah}^{-1-}$ mice (C57B1/6) (17), 3 to 4 mo old, were maintained in a temperature-controlled environment with a 12-h light/dark cycle and allowed food (Special Diets Services, Essex, UK) ad libitum. Animals were treated according to the guidelines of the Dutch Animal Ethical Committee. All animals received drinking water provided with NTBC (1 $\mathrm{mg} / \mathrm{kg}$ body weight/d) (Swedish Orphan AB, Stockholm, Sweden). NTBC was provided from the fetal stage on by treatment $(4 \mathrm{mg} / \mathrm{kg}$ body weight $/ \mathrm{d})$ of the pregnant and nursing females.

Experimental approach. To induce the HT1 phenotype, NTBC was withdrawn from adult $\mathrm{Fah}^{-1-}$ mice for $15 \mathrm{~d}(18,19)$. To study the development of liver and kidney damage, $\mathrm{Fah}^{-/-}$mice on and off NTBC were injected intraperitoneally with a single dose of 800 (18), 400, 200, or 100 $\mathrm{mg} / \mathrm{kg}$ body weight HGA (Sigma Chemical Co., St. Louis, MO). All mice were killed by cervical dislocation. The mice receiving $800 \mathrm{mg} / \mathrm{kg}$ HGA were killed $4 \mathrm{~h}$ after injection; those receiving $400 \mathrm{mg} / \mathrm{kg}$ HGA were killed 4 and $18 \mathrm{~h}$ after injection, and the mice receiving 200 and $100 \mathrm{mg} / \mathrm{kg}$ HGA were killed 4,18 , and $48 \mathrm{~h}$ after injection. The experimental groups consisted of two to four age-matched mice. Parts of the liver and kidneys of each mouse were fixed in a mixture containing a 2:2:1 ratio of methanol:acetone:water, and the rest of the liver and kidneys were snap frozen in liquid nitrogen and stored at $-70^{\circ} \mathrm{C}$.

Histologic and histochemical examinations. For microscopic examination, tissues were dehydrated in a series of graded ethanol and embedded in paraffin wax at $58^{\circ} \mathrm{C}$. Sections were stained with hematoxylin and eosin for histomorphologic evaluation and used for immunohistochemical detection of the processed form of caspase- 3 according to manufacturer's instructions (Cell Signaling Technology, Beverly, MA).

The 3'-OH DNA ends resulting from DNA fragmentation were labeled using the TUNEL assay (Promega, Madison, WI), according to the manufacturer's instructions. The labeled $3^{\prime}-\mathrm{OH}$ DNA ends were visualized using $3,3^{\prime}$-diaminobenzidine. Lightgreen $(0.2 \%)$ was used for counterstaining.

For evaluating cleaved caspase-3-positive and TUNEL-positive cells, four randomly chosen areas per section were analyzed. In each area, 100 hepatocytes in liver sections and 100 tubules in kidney sections were deemed positive or negative by two independent examiners.
Biochemical analyses in urine and blood. After decapitation, blood was collected and immediately mixed with sodium heparin. Plasma was separated and stored at $-20^{\circ} \mathrm{C}$. Urine was collected before the mice were killed. Plasma levels of creatinine, urea, glucose, and alkaline phosphatase and urinary creatinine, urea, and glucose were measured using an automated analyzer (VITROS Chemistry Products, Ortho-Clinical Diagnostics, Inc., Rochester, NY).

\section{RESULTS}

Clinical features and macroscopic examination of tissues of experimental $\mathrm{Fah}^{-/-}$mice on and off NTBC. Fah ${ }^{-/-}$ mice on and off NTBC were subjected to intraperitoneal administration of various doses of HGA and harvested at different time points after injection to enable the study of the pathology associated with FAH deficiency. The clinical symptoms and macroscopic appearance of the liver and kidneys of the experimental mice were assessed. Unchallenged $\mathrm{Fah}^{-/-}$ mice on NTBC had a healthy phenotype (17). NTBC-treated $\mathrm{Fah}^{-1-}$ mice became ill $2 \mathrm{~h}$ after injection of $800 \mathrm{mg} / \mathrm{kg} \mathrm{HGA}$ and showed signs of severe illness when killed $4 \mathrm{~h}$ after injection, as has been described previously (18). They were markedly less affected by administration of $400 \mathrm{mg} / \mathrm{kg}$ HGA, displaying diminished activity as the sole sign of illness $18 \mathrm{~h}$ after injection. They showed no signs of illness at any investigated time point after injection of 200 or $100 \mathrm{mg} / \mathrm{kg}$ of HGA. Livers of NTBC-treated $\mathrm{Fah}^{-1-}$ mice, either unchallenged or challenged with any of the investigated doses of HGA, had a normal macroscopic appearance. The kidneys of these mice were enlarged and pale 18 and $48 \mathrm{~h}$ after challenge with 200 or $100 \mathrm{mg} / \mathrm{kg}$ HGA.

$\mathrm{Fah}^{-1-}$ mice from which NTBC had been withdrawn for $15 \mathrm{~d}$ had a very mild clinical phenotype, the only apparent feature being an increased production of urine. They did not show any additional clinical features after challenge with 800 , 400,200 , or $100 \mathrm{mg} / \mathrm{kg} \mathrm{HGA}$ up to the time points of harvesting. The livers and kidneys of all $\mathrm{Fah}^{-\prime-}$ mice from which NTBC had been withdrawn for $15 \mathrm{~d}$ were enlarged and pale as a result of the progression of HT1, so that their macroscopic appearance could not be used to evaluate damage due to HGA injection.

Histologic examination of liver and kidneys of experimental $\mathrm{Fah}^{-1-}$ mice on and off NTBC. The livers and kidneys of NTBC-treated $\mathrm{Fah}^{-1-}$ mice showed normal histology. Challenging $\mathrm{Fah}^{-1-}$ mice on NTBC with $800 \mathrm{mg} / \mathrm{kg} \mathrm{HGA}$ revealed diffuse vacuolization within hepatocytes $4 \mathrm{~h}$ after HGA administration (Fig. 2B), whereas loss of cell-cell adhesion, nuclear shrinkage as well as chromatin condensation, and widening of the tubular lumina was seen in kidneys (18). Swollen hepatocytes (not shown) could be detected $4 \mathrm{~h}$ after challenge with $400 \mathrm{mg} / \mathrm{kg}$ HGA in the livers of NTBC-treated $\mathrm{Fah}^{-1-}$ mice, but $18 \mathrm{~h}$ after injection, the livers had a normal appearance. The kidneys of these mice, when examined $4 \mathrm{~h}$ after HGA injection, revealed dilated tubules, loss of cell-cell adhesion, and nuclear shrinkage in some of the tubules. Additionally, extensive tubular degeneration and intraluminal protein casts could be detected $18 \mathrm{~h}$ after HGA administration. A single dose of 200 or $100 \mathrm{mg} / \mathrm{kg} \mathrm{HGA}$ did not lead to histologic changes in the livers of NTBC-treated $\mathrm{Fah}^{-/-}$mice at any time point investigated (Fig. 2A). Their kidneys, however, showed many histologic features of cell and tissue damage, both 18 and $48 \mathrm{~h}$ 

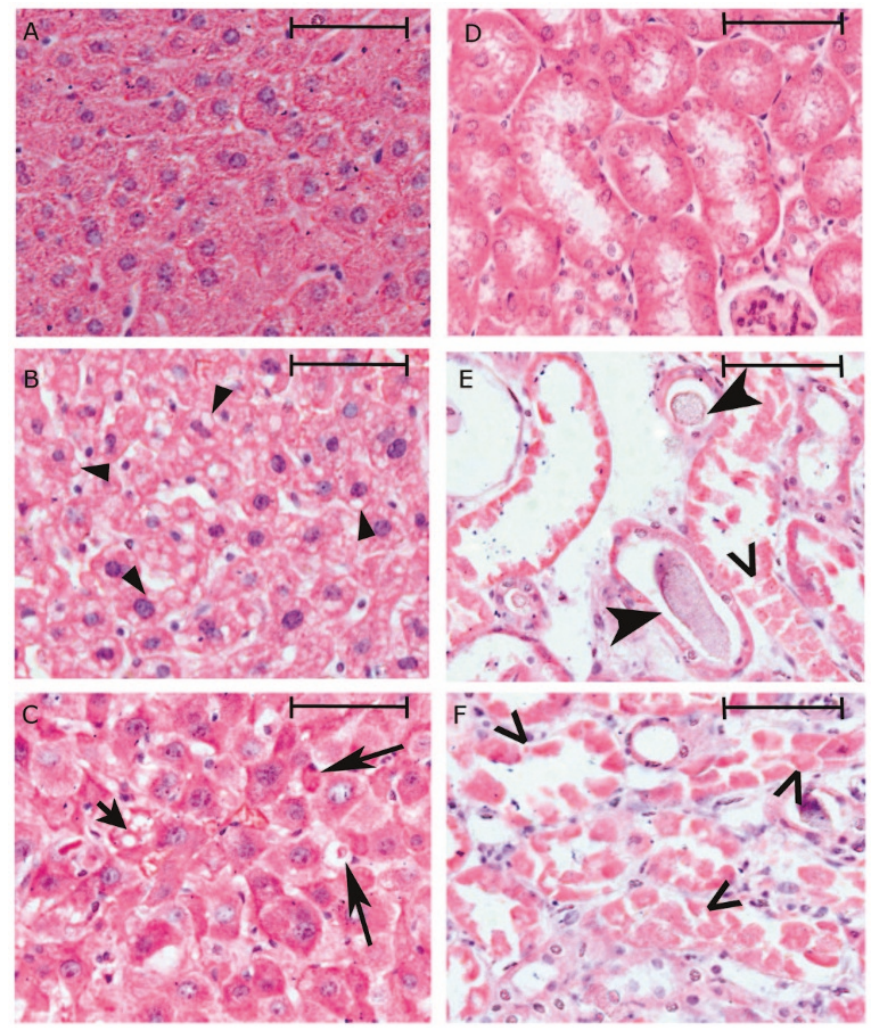

Figure 2. Hematoxylin-eosin staining of livers and kidneys of several experimental $\mathrm{Fah}^{-1-}$ mice. Examples of histologic features observed in differently treated livers and kidneys of $\mathrm{Fah}^{-/-}$mice. (A) Liver $4 \mathrm{~h}$ after challenging $\mathrm{Fah}^{-/-}$mice on NTBC with $100 \mathrm{mg} / \mathrm{kg} \mathrm{HGA}$, similar to normal liver. The same was found for livers of $\mathrm{Fah}^{-1-}$ mice on NTBC 4, 18, and $48 \mathrm{~h}$ after administration of 100 or $200 \mathrm{mg} / \mathrm{kg}$ HGA. (B) Diffuse vacuolization of hepatocytes $4 \mathrm{~h}$ after challenge of NTBC-treated $\mathrm{Fah}^{-\prime-}$ mice with 800 $\mathrm{mg} / \mathrm{kg}$ HGA (small arrowhead). (C) Signs of apoptosis (large arrow) and fatty degeneration of hepatocytes (small arrow) $4 \mathrm{~h}$ after challenging $\mathrm{Fah}^{-/-}$ mice off NTBC with $100 \mathrm{mg} / \mathrm{kg}$ HGA. This is representative for livers of all $\mathrm{Fah}^{-1-}$ mice off NTBC, both unchallenged and challenged with HGA. (D) Normal histology of the kidney $4 \mathrm{~h}$ after challenging $\mathrm{Fah}^{-1-}$ mice off NTBC with $100 \mathrm{mg} / \mathrm{kg}$ HGA. Similar results were obtained $4 \mathrm{~h}$ after challenging NTBC-treated $\mathrm{Fah}^{-1-}$ mice with 100 and $200 \mathrm{mg} / \mathrm{kg} \mathrm{HGA}, 4 \mathrm{~h}$ after challenging $\mathrm{Fah}^{-/-}$mice off NTBC with $200 \mathrm{mg} / \mathrm{kg}$ of HGA, and $18 \mathrm{~h}$ after challenging $\mathrm{Fah}^{-/-}$mice off NTBC with 100 and $200 \mathrm{mg} / \mathrm{kg}$ of HGA. $(E, F)$ Signs of degeneration of tubules (open triangle) accumulation of eosinophilic material in the lumina of the tubules (closed triangle) were seen $48 \mathrm{~h}$ after challenge of $\mathrm{Fah}^{-/-}$mice on NTBC with $200 \mathrm{mg} / \mathrm{kg}$ of HGA. Similar features were observed with $100 \mathrm{mg} / \mathrm{kg}$ HGA and in the kidneys of $\mathrm{Fah}^{-1-}$ mice off NTBC $48 \mathrm{~h}$ after challenge with 100 and $200 \mathrm{mg} / \mathrm{kg}$ HGA. The scale bar represents $50 \mu \mathrm{m}$.

after administration of 200 or $100 \mathrm{mg} / \mathrm{kg}$ of HGA. The degree of degeneration of the tubules varied from moderate (Fig. $2 E$ ) to severe (Fig. $2 F$ ). Tubules were dilated and contained abundant eosinophilic material (Fig. 2E).

Hepatocytes of $\mathrm{Fah}^{-/-}$mice off NTBC for $15 \mathrm{~d}$ showed anisocytosis, signs of apoptosis and vacuolization consistent with fatty degeneration (Fig. 2C) (20). Kidneys of $\mathrm{Fah}^{-1-}$ mice withdrawn from NTBC revealed tubular dilatation as single feature of damage (Fig. 2D). The histologic features of the liver did not change when $\mathrm{Fah}^{-1-}$ mice off NTBC were challenged with various doses of HGA. Challenge of $\mathrm{Fah}^{-/-}$ mice off NTBC with 200 or $100 \mathrm{mg} / \mathrm{kg}$ HGA did lead to proximal tubular dilatation and accumulation of eosinophilic

material in the tubules $48 \mathrm{~h}$ after administration, suggesting that, upon NTBC withdrawal, kidneys of $\mathrm{Fah}^{-\prime-}$ mice become partially but not completely resistant to damage induced by low doses of HGA.

Analysis of cell death in liver and kidneys of experimental $\mathrm{Fah}^{-/-}$mice on and off NTBC. The extent and mode of cell death in the liver and kidneys of $\mathrm{Fah}^{-1-}$ mice induced by exposure to HGA were examined by TUNEL assay and immunohistochemical analysis of cleaved caspase- 3 expression (Table 1). Unchallenged $\mathrm{Fah}^{-1-}$ mice on NTBC revealed no features of cell death in the liver and kidneys (not shown). Challenge of NTBC-treated $\mathrm{Fah}^{-/-}$mice with $800 \mathrm{mg} / \mathrm{kg}$ HGA resulted in extensive TUNEL-positive staining of both hepatocytes (Table 1, Fig. $3 E$ ) and renal proximal tubular cells (18) $4 \mathrm{~h}$ after HGA administration, but staining for cleaved caspase- 3 was negative (Table 1). Only a few TUNEL-positive hepatocytes were detected 4 and $18 \mathrm{~h}$ after administration of $400 \mathrm{mg} / \mathrm{kg} \mathrm{HGA}$ to NTBC-treated $\mathrm{Fah}^{-/-}$mice, whereas TUNEL-positive tubules were abundantly present in the renal cortex of these mice (Table 1). Cleaved caspase- 3 staining of renal cells was negative $4 \mathrm{~h}$ after challenge with $400 \mathrm{mg} / \mathrm{kg}$ HGA but became slightly positive $18 \mathrm{~h}$ after injection (Table 1). Administration of 200 and 100 mg/kg HGA to NTBC-treated $\mathrm{Fah}^{-/-}$mice did not yield TUNEL-positive staining of hepatocytes or staining of hepatocytes for cleaved caspase-3 (Fig. 3C, Table 1) 4, 18, and $48 \mathrm{~h}$ after HGA administration. In contrast, the kidneys of these mice contained many TUNEL-positive tubules 18 and $48 \mathrm{~h}$ after challenge (Fig. $4 C$, Table 1). Staining for cleaved caspase-3 was also positive for a subset of their renal tubules (Table 1), but not to the same extent as the TUNEL reaction. This shows that the kidneys of NTBC-treated $\mathrm{Fah}^{-/-}$mice are strikingly more sensitive to both a cleaved caspase-3-dependent and a cleaved caspase-3-independent HGA-induced cell death than the liver.

Challenging $\mathrm{Fah}^{-1-}$ mice, which had been off NTBC for $15 \mathrm{~d}$ with any of the doses of HGA led to TUNEL-positive staining of only occasional cells in the liver and kidneys under all experimental circumstances (Figs. 3 and 4). Cleaved caspase- 3 was detected in a limited number of renal cells of $\mathrm{Fah}^{-1-}$ mice off NTBC $48 \mathrm{~h}$ after challenge with 200 and 100 $\mathrm{mg} / \mathrm{kg}$ of HGA (Table 1). Thus, resistance developed after NTBC was withdrawn to cell death induced by HGA in both the liver and kidneys of $\mathrm{Fah}^{-1-}$ mice.

Biochemical analyses in plasma and urine of experimental $\mathrm{Fah}^{-1-}$ mice on and off NTBC. NTBC-treated $\mathrm{Fah}^{-1-}$ mice had normal plasma glucose levels and alkaline phosphatase concentrations, whether unchallenged or challenged with different doses of HGA. Features of kidney dysfunction were present $18 \mathrm{~h}$ after administration of 400,200, and $100 \mathrm{mg} / \mathrm{kg}$ HGA, as was evidenced by detection of elevated levels of plasma urea (Fig. 5A2) and plasma creatinine (Fig. 5B2) and decreased levels of urea and creatinine in urine (not shown). In addition, urine glucose levels of these mice were increased on HGA challenge (not shown), suggesting a reduced reabsorption of glucose by the renal tubules. We concluded that relatively low doses of HGA caused renal dysfunction but did not affect the investigated markers of liver function in NTBCtreated $\mathrm{Fah}^{-1-}$ mice. 
Table 1. Overview of TUNEL and caspase-3-positive staining in livers and kidneys of Fah ${ }^{-1-}$ mice on and off NTBC challenged with different doses of HGA and killed 4, 18, and 48 h after HGA administration

\begin{tabular}{|c|c|c|c|c|c|c|c|c|c|c|}
\hline & & \multicolumn{4}{|c|}{$4 \mathrm{~h}$} & \multicolumn{3}{|c|}{$18 \mathrm{~h}$} & \multicolumn{2}{|c|}{$48 \mathrm{~h}$} \\
\hline & & $100 \mathrm{mg} / \mathrm{kg}$ & $200 \mathrm{mg} / \mathrm{kg}$ & $400 \mathrm{mg} / \mathrm{kg}$ & $800 \mathrm{mg} / \mathrm{kg}$ & $100 \mathrm{mg} / \mathrm{kg}$ & $200 \mathrm{mg} / \mathrm{kg}$ & $400 \mathrm{mg} / \mathrm{kg}$ & $100 \mathrm{mg} / \mathrm{kg}$ & $200 \mathrm{mg} / \mathrm{kg}$ \\
\hline \multicolumn{11}{|l|}{ Liver } \\
\hline \multirow[t]{2}{*}{ On NTBC } & TUNEL & - & - & - & ++ & - & - & - & - & - \\
\hline & Caspase-3 & - & - & - & - & - & - & - & - & - \\
\hline \multirow[t]{2}{*}{ Off NTBC } & TUNEL & - & - & - & - & - & - & - & - & - \\
\hline & Caspase-3 & - & - & - & - & - & - & - & - & - \\
\hline \multicolumn{11}{|l|}{ Kidney } \\
\hline \multirow[t]{2}{*}{ On NTBC } & TUNEL & - & +++ & ++ & ++++ & +++ & +++ & +++ & n.s. & n.s. \\
\hline & Caspase-3 & - & - & - & - & ++ & + & + & n.s & n.s. \\
\hline \multirow[t]{2}{*}{ Off NTBC } & TUNEL & - & - & - & + & - & - & - & + & - \\
\hline & Caspase-3 & - & - & - & - & - & - & - & + & + \\
\hline
\end{tabular}

The percentage of positive hepatocytes is scored in the livers and the percentage of positive tubules is scored in the kidneys of differently treated $F^{-1-} h^{-}$mice. Less than $1 \%(-), 1-5 \%(+), 5-15 \%(++), 15-50 \%(+++)$, and $>50 \%(++++)$ positive cells or tubules were detected. Some kidneys were damaged to such an extent that the percentage of positive tubules could not be estimated due to tubules that were no longer intact. n.s., cannot be scored.
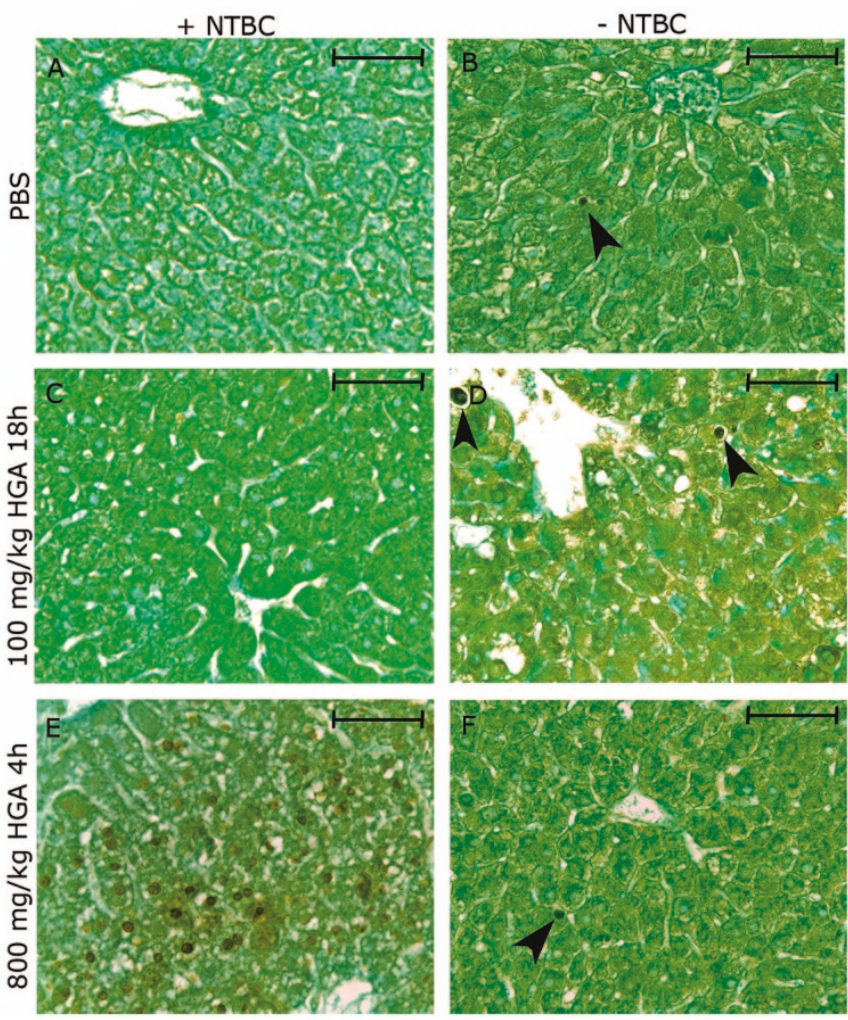

Figure 3. TUNEL staining of the livers of $\mathrm{Fah}^{-1-}$ mice on and off NTBC after exposure to 100 and $800 \mathrm{mg} / \mathrm{kg} \mathrm{HGA}$. Fah ${ }^{-1-}$ mice on $(A, C, E)$ and off $(B, D, F)$ NTBC were injected with phosphate-buffered saline (PBS) $(A, B)$, $100 \mathrm{mg} / \mathrm{kg} \mathrm{HGA}(C, D)$, or $800 \mathrm{mg} / \mathrm{kg}$ HGA $(E, F)$. PBS-injected mice and mice challenged with $100 \mathrm{mg} / \mathrm{kg}$ HGA were killed $18 \mathrm{~h}$ after injection and $\mathrm{Fah}^{-1-}$ mice injected with $800 \mathrm{mg} / \mathrm{kg}$ HGA were killed after $4 \mathrm{~h}$. All livers were analyzed for the presence of DNA double-strand breaks using the TUNEL assay. Only a few TUNEL-positive nuclei (closed triangle) were seen in livers of $\mathrm{Fah}^{-\prime-}$ mice off NTBC $18 \mathrm{~h}$ after injection of PBS (B), 18 $\mathrm{h}$ after administration of $100 \mathrm{mg} / \mathrm{kg}$ HGA $(D)$, or $4 \mathrm{~h}$ after administration of $800 \mathrm{mg} / \mathrm{kg} \mathrm{HGA}(F)$. The scale bar represents $50 \mu \mathrm{m}$.

$\mathrm{Fah}^{-1-}$ mice from which NTBC had been withdrawn showed decreased plasma glucose levels (Fig. 5C3). Plasma alkaline phosphatase levels of these mice were increased (Fig. $5 D 3)$. Subtyping of alkaline phosphatase yielded liver and bone subtypes in approximately equal amounts (not shown), indicating damage of parenchymal liver cells and increased
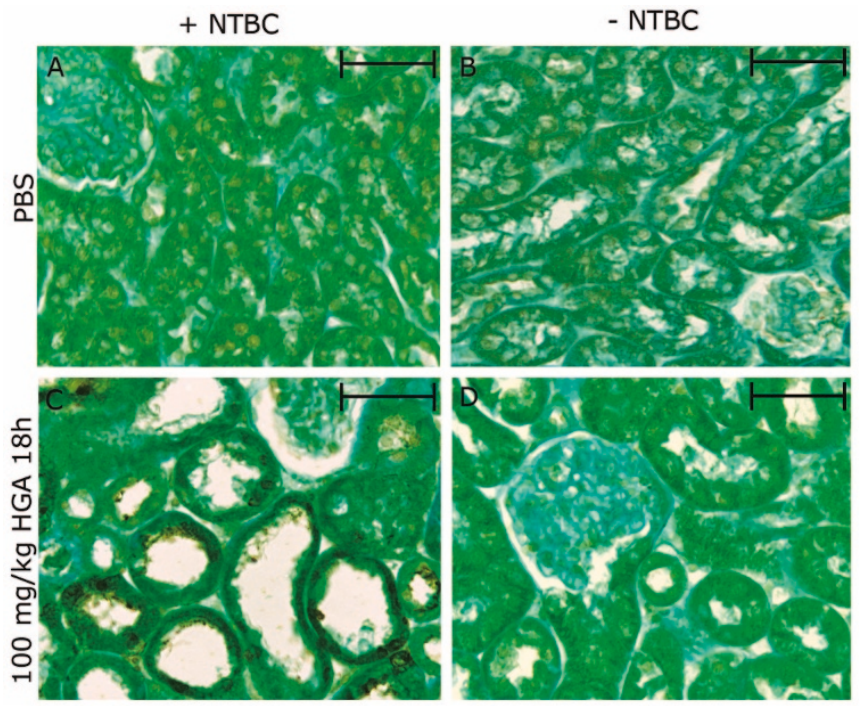

Figure 4. TUNEL staining of the kidneys of $\mathrm{Fah}^{-/-}$mice on and off NTBC after exposure to $100 \mathrm{mg} / \mathrm{kg} \mathrm{HGA}$. Fah ${ }^{-1-}$ mice on $(A, C)$ and off $(B, D)$ NTBC and injected with PBS $(A, B)$ or with $100 \mathrm{mg} / \mathrm{kg}$ HGA $(C, D)$ were killed $18 \mathrm{~h}$ after injection, and their kidneys were analyzed for the presence of DNA double-strand breaks using the TUNEL assay. TUNEL-positive cells were only present $18 \mathrm{~h}$ after challenging $\mathrm{Fah}^{-/-}$mice on NTBC with 100 $\mathrm{mg} / \mathrm{kg}$ HGA $(C)$. The scale bar represents $50 \mu \mathrm{m}$.

activity of osteoblasts, possibly due to loss of phosphate by the kidneys. Kidney dysfunction became apparent in some, but not all, mice $48 \mathrm{~h}$ after injection with 200 or $100 \mathrm{mg} / \mathrm{kg}$ HGA (Fig. 5A3, B3). This suggests that the acquired protection from cell death is associated with partial but not complete protection from kidney dysfunction induced by relatively low doses of HGA.

\section{DISCUSSION}

The pathogenesis of liver and kidney damage caused by HT1 begins to be revealed, thanks to the availability of a mouse model for the disease that allows detailed analysis of HT1-associated processes in the liver and kidneys. However, many questions concerning the relatively new treatment with NTBC and the potential residual risks for treated HT1 patients remain to be answered. The previously reported massive cell death in both the liver and kidneys of NTBC-treated $\mathrm{Fah}^{-/-}$ 
A1
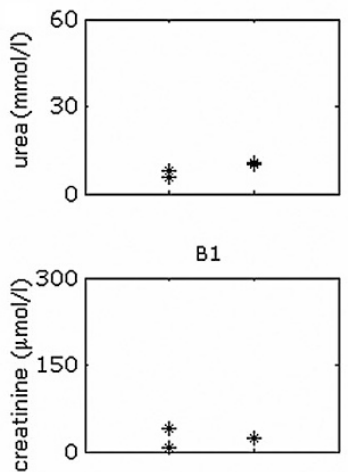

C1

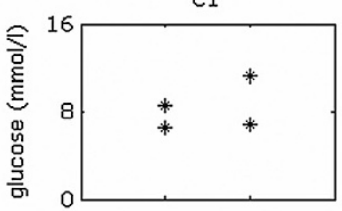

D1

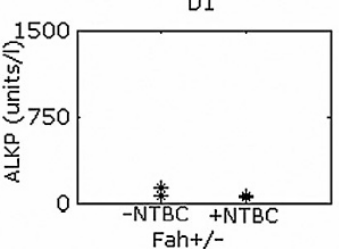

A2

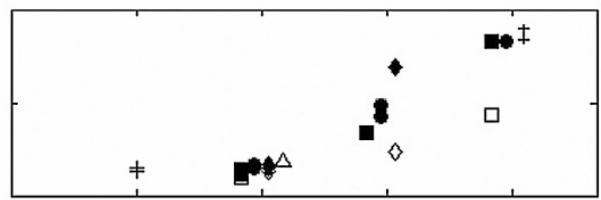

B2

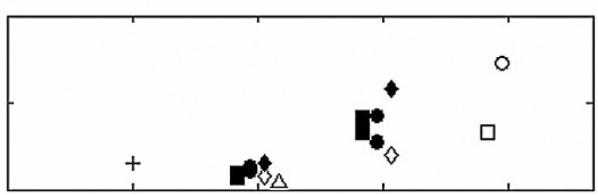

$\mathrm{C} 2$

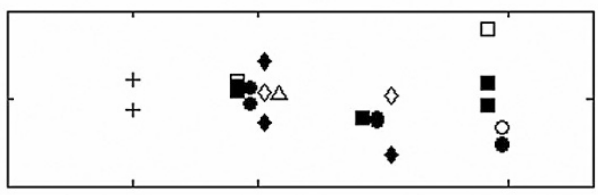

D2

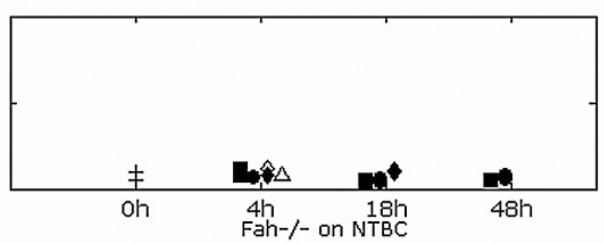

A3

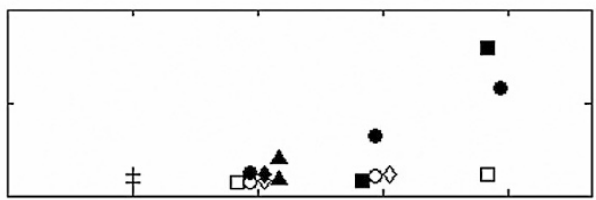

B3

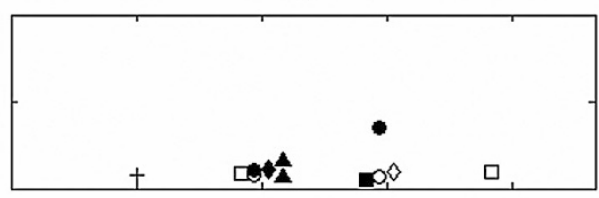

C3
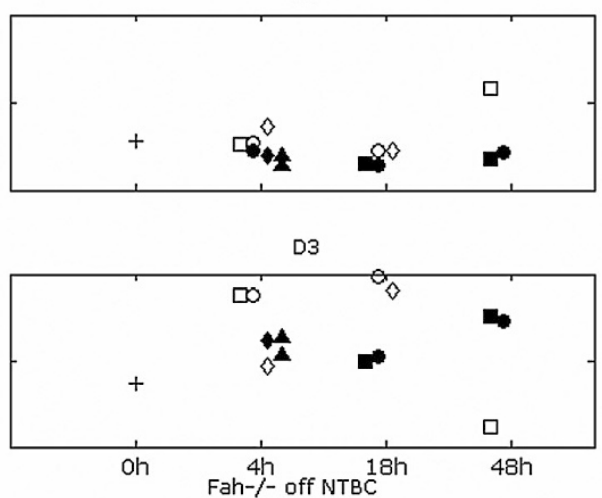

Figure 5. Influence of an HGA challenge on kidney and liver function of $\mathrm{Fah}^{-1-}$ mice on and off NTBC. Blood samples of male (closed symbols) and female (open symbols) $\mathrm{Fah}^{-1-}$ mice on (A2-D2) and off (A3-D3) NTBC, which had been treated with varying amounts of HGA, were obtained $0,4,18$, and $48 \mathrm{~h}$ after HGA administration and analyzed for plasma urea $(A)$, plasma creatinine $(B)$, plasma glucose $(C)$, and plasma alkaline phosphatase $(D)$. Unchallenged $(+)$ mice or mice challenged with $100 \mathrm{mg} / \mathrm{kg} \mathrm{HGA}(\boldsymbol{\square}, \square), 200 \mathrm{mg} / \mathrm{kg} \mathrm{HGA}(\bullet, \bigcirc), 400 \mathrm{mg} / \mathrm{kg} \mathrm{HGA}(\diamond, \diamond)$, and $800 \mathrm{mg} / \mathrm{kg} \operatorname{HGA}(\Delta, \boldsymbol{\Delta})$ were used. If the same value was found in more than one mouse, it is indicated by $\$$.

mice has only been detected after exposure to high doses of HGA. Similarly, the acquired resistance of hepatocytes and renal tubular cells to this mode of cell death when NTBC is withdrawn from $\mathrm{Fah}^{-/-}$mice is related to a challenge with high doses of HGA $(18,19)$. We have now extended our investigation of the pathogenesis of HT1-related liver and kidney damage by studying the effects of various doses of HGA on NTBC-treated $\mathrm{Fah}^{-1-}$ mice as well as the consequences of NTBC withdrawal preceding the HGA challenges.

The in vivo administration of HGA to NTBC-treated $\mathrm{Fah}^{-/-}$mice, which will result in acute accumulation of FAA in both liver and kidneys, allows comparison of the sensitivity of these organs to the induction of cell death within individual mice. Interestingly, our experiments consistently show that the kidneys of NTBC-treated $\mathrm{Fah}^{-1-}$ mice are far more sensitive to cell death induced by HGA than the liver. It is not clear which features determine the tissue-specific sensitivity to induction of cell death on HGA administration. Previous investigations suggest the involvement of oxidative stress in HT1-associated cell death $(17,21-23)$. It may be that the liver is better equipped to meet the consequences of oxidative stress than the kidney. It has, for instance, been shown that the liver of rats contains more reduced glutathione than the kidneys (24). However, further studies are necessary to elucidate the mechanism underlying the relative sensitivity of the kidney to HGA-induced damage. Based on our findings, we speculate that the liver failure, which is the predominant feature and main cause of death in patients diagnosed with the acute form of HT1 (2) that is often accompanied by complete absence of FAH protein $(25,26)$, is caused by exposure to relatively high amounts of FAA. It is likewise plausible that renal tubular dysfunction, which is the most common presentation of the disease in patients with the chronic form of HT1 (2) and accompanied by residual FAH immunoreactivity $(25,26)$, is the consequence of exposure to relatively low doses of FAA.

The observation that the kidneys of $\mathrm{Fah}^{-1-}$ mice on NTBC are extremely sensitive to HGA-induced cell death raises the serious concern that NTBC-treated HT1 patients may be at risk of developing renal problems. Indeed, kidneys of HT1 patients will be exposed to relatively low amounts of FAA during NTBC treatment if the dose of NTBC used is not able to sufficiently inhibit HPD (15) or if NTBC intake by patients fluctuates. Unfortunately, few data on kidney function have been reported for human HT1 patients on NTBC therapy and it is, therefore, not known whether renal deterioration occurs in these patients. Based on the current findings and on the knowledge that kidney deterioration does not become clinically apparent until most of the kidney function is lost, it is advisable to strictly monitor HT1 patients being treated with NTBC, not only for the development of HCC, but also for early signs of renal dysfunction. 
Withdrawing NTBC from $\mathrm{Fah}^{-1-}$ mice will lead to a gradual accumulation of FAA, whereby the loss of inhibition of HPD due to NTBC withdrawal will be partially compensated for by down-regulation of HPD expression due to increased FAA concentration (27). The limited damage of the kidneys of $\mathrm{Fah}^{-1-}$ mice taken off NTBC for $15 \mathrm{~d}$ shows that their kidneys are able to cope with this gradual increase in FAA concentration, probably as a result of induction of proteins protecting the kidney from oxidative damage. HGA enters the tyrosine breakdown cascade downstream of the reaction catalyzed by HPD (Fig. 1), so that FAA-induced down-regulation of HPD in tissues of $\mathrm{Fah}^{-/-}$mice off NTBC will not influence the additional exposure to FAA on HGA administration. The kidneys of $\mathrm{Fah}^{-1-}$ mice off NTBC become resistant to cell death induced by low doses of HGA, although they are not completely protected from deterioration on exposure to HGA. The inappropriate resistance to deathinducing stimuli may render these renal cells sensitive to accumulation of DNA mutations, ultimately resulting in the development of cancer. Although cancer of the kidney is no feature of the mouse $\mathrm{Fah}^{-/-}$phenotype and has not been reported or found in patients with HT1 (F.J. van Spronsen Groningen University Medical Centre, personal communication 2005), it cannot be ruled out that renal cancer may eventually develop in HT1 patients who underwent liver transplantation and do not receive NTBC treatment after OLT. These patients continue to excrete low amounts of succinylacetone in the urine $(6,10)$ due to the persistence of the enzyme defect in the kidneys $(1,9)$. Their kidneys are, therefore, constantly exposed to FAA that is produced locally and may acquire resistance to cell death, as has been found for $\mathrm{Fah}^{-/-}$ mice. In addition, the continuous local FAA production may lead to progressive loss of function of the kidney because our results indicate that the protection from damage by the resistance to cell death is incomplete in $\mathrm{Fah}^{-/-}$mice. These considerations also apply to HT1 patients who have recovered spontaneously from the disease due to somatic reversion of one of the disease-causing DNA mutations followed by clonal expansion of reverted hepatocytes, thereby resolving severe liver damage and rickets (28). These patients have been shown to be at risk of developing HCC due to the persistence of nonreverted hepatocytes, and their kidneys will likewise be prone to damage by locally produced FAA.

In conclusion, our study, which reveals that the kidney in particular of $\mathrm{Fah}^{-/-}$mice on NTBC is sensitive to damage induced by low doses of HGA, prompts the necessity to perform additional research on the kidney function of HT1 patients who are treated with NTBC, underwent OLT, or recovered from the disease as a result of expansion of reverted hepatocytes. Until more is known about the putative deterioration of renal function in these patients, physicians should actively monitor the kidney function of each HT1 patient.

Acknowledgments. We gratefully thank Markus Grompe (Oregon Health Science University, Portland, OR) for providing the Fah-deficient mice, Ted van den Ingh for evaluation and description of liver and kidney damage, Margriet Hendriks for help with illustrations, and Theo Meijerink for biochemical analyses. Swedish Orphan AB, Stockholm, Sweden, kindly supplied NTBC.

\section{REFERENCES}

1. Kvittingen EA 1986 Hereditary tyrosinemia type I-an overview. Scand J Clin Lab Invest Suppl 184:27-34

2. Weinberg AG, Mize CE, Worthen HG 1976 The occurrence of hepatoma in the chronic form of hereditary tyrosinemia. J Pediatr 88:434-438

3. Kvittingen EA 1995 Tyrosinaemia-treatment and outcome. J Inherit Metab Dis 18:375-379

4. van Spronsen FJ, Thomasse Y, Smit GP, Leonard JV, Clayton PT, Fidler V, Berger R, Heymans HS 1994 Hereditary tyrosinemia type I: a new clinical classification with difference in prognosis on dietary treatment. Hepatology 20:1187-1191

5. Russo PA, Mitchell GA, Tanguay RM 2001 Tyrosinemia: a review. Pediatr Dev Pathol 4:212-221

6. Shoemaker LR, Strife CF, Balistreri WF, Ryckman FC 1992 Rapid improvement in the renal tubular dysfunction associated with tyrosinemia following hepatic replacement. Pediatrics 89:251-255

7. Forget S, Patriquin HB, Dubois J, Lafortune M, Merouani A, Paradis K, Russo P 1999 The kidney in children with tyrosinemia: sonographic, CT and biochemical findings. Pediatr Radiol 29:104-108

8. Kvittingen EA, Talseth T, Halvorsen S, Jakobs C, Hovig T, Flatmark A 1991 Renal failure in adult patients with hereditary tyrosinaemia type I. J Inherit Metab Dis 14:53-62

9. Laine J, Salo MK, Krogerus L, Karkkainen J, Wahlroos O, Holmberg C 1995 The nephropathy of type I tyrosinemia after liver transplantation. Pediatr Res 37:640-645

10. Tuchman M, Freese DK, Sharp HL, Ramnaraine ML, Ascher N, Bloomer JR 1987 Contribution of extrahepatic tissues to biochemical abnormalities in hereditary tyrosinemia type I: study of three patients after liver transplantation. J Pediatr 110:399-403

11. Lindstedt S, Holme E, Lock EA, Hjalmarson O, Strandvik B 1992 Treatment of hereditary tyrosinaemia type I by inhibition of 4-hydroxyphenylpyruvate dioxygenase. Lancet 340:813-817

12. Grompe M 2001 The pathophysiology and treatment of hereditary tyrosinemia type 1. Semin Liver Dis 21:563-571

13. Holme E, Lindstedt S 1995 Diagnosis and management of tyrosinemia type I. Curr Opin Pediatr 7:726-732

14. Pronicka E, Rowinska E, Bentkowski Z, Zawadzki J, Holme E, Lindstedt S 1996 Treatment of two children with hereditary tyrosinaemia type I and long-standing renal disease with a 4-hydroxyphenylpyruvate dioxygenase inhibitor (NTBC). J Inherit Metab Dis 19:234-238

15. Holme E, Lindstedt S 1998 Tyrosinaemia type I and NTBC (2-(2-nitro-4trifluoromethylbenzoyl)-1,3-cyclohexanedione). J Inherit Metab Dis 21:507-517

16. van Spronsen FJ, Bijleveld CM, van Maldegem BT, Wijburg FA 2005 Hepatocellular carcinoma in hereditary tyrosinemia type I despite 2-(2 nitro-4-3 trifluoromethylbenzoyl)-1, 3-cyclohexanedione treatment. J Pediatr Gastroenterol Nutr 40:90-93

17. Grompe M, Lindstedt S, Al Dhalimy M, Kennaway NG, Papaconstantinou J, Torres-Ramos CA, Ou CN, Finegold M 1995 Pharmacological correction of neonatal lethal hepatic dysfunction in a murine model of hereditary tyrosinaemia type I. Nat Genet 10:453-460

18. Luijerink MC, van Beurden EA, Malingre HE, Jacobs SM, Grompe M, Klomp LW, Berger R, van denBerg IE 2004 Renal proximal tubular cells acquire resistance to cell death stimuli in mice with hereditary tyrosinemia type 1. Kidney Int 66:9901000

19. Vogel A, van den Berg IE, Al-Dhalimy M, Groopman J, Ou CN, Ryabinina O, Iordanov MS, Finegold M, Grompe M 2004 Chronic liver disease in murine hereditary tyrosinemia type 1 induces resistance to cell death. Hepatology 39:433443

20. Gentz J, Jagenburg R, Zetterstroem R 1965 Tyrosinemia. J Pediatr 66:670-96:670 696

21. Jorquera R, Tanguay RM 1997 The mutagenicity of the tyrosine metabolite, fumarylacetoacetate, is enhanced by glutathione depletion. Biochem Biophys Res Commun 232:42-48

22. Jorquera R, Tanguay RM 2001 Fumarylacetoacetate, the metabolite accumulating in hereditary tyrosinemia, activates the ERK pathway and induces mitotic abnormalities and genomic instability. Hum Mol Genet 10:1741-1752

23. Luijerink MC, Jacobs SM van Beurden EA, Koornneef LP, Klomp LW, Berger R van den Berg IE 2003 Extensive changes in liver gene expression induced by hereditary tyrosinemia type I are not normalized by treatment with 2-(2-nitro-4trifluoromethylbenzoyl)-1,3-cyclohexanedione (NTBC). J Hepatol 39:901-909

24. Aydin C, Ince E, Koparan S, Cangul IT, Naziroglu M, Ak F 2005 Protective effects of long term dietary restriction on swimming exercise-induced oxidative stress in the liver, heart and kidney of rat. Cell Biochem Funct [Epub ahead of print]

25. Kvittingen EA, Rootwelt H, van Dam T, van Faassen H, Berger R 1992 Hereditary tyrosinemia type I: lack of correlation between clinical findings and amount of immunoreactive fumarylacetoacetase protein. Pediatr Res 31:43-46

26. Tanguay RM, Valet JP, Lescault A, Duband JL, Laberge C, Lettre F, Plante M 1990 Different molecular basis for fumarylacetoacetate hydrolase deficiency in the two clinical forms of hereditary tyrosinemia (type I). Am J Hum Genet 47:308-316

27. Lindblad B, Lindstedt S, Steen G 1977 On the enzymic defects in hereditary tyrosinemia. Proc Natl Acad Sci U S A 74:4641-4645

28. Kim SZ, Kupke KG, Ierardi-Curto L, Holme E, Greter J, Tanguay RM, Poudrier J, D'Astous M, Lettre F, Hahn SH, Levy HL 2000 Hepatocellular carcinoma despite long-term survival in chronic tyrosinaemia I. J Inherit Metab Dis 23:791-804 